\title{
Working Capital towards Royal Enfield In Venkateshwara Bike Zone
}

\author{
CS. Gowtham Chakravarthy, S.Praveen Kumar, G.Madhan
}

\begin{abstract}
School understudies from all of the three fields of direction are revealed to strain; in any case, usually extraordinarily collecting school understudies are parts less in risk to the improvement of strain in appraisal to helpful and dental school understudies. Further assessments should be done to examine the elucidations inside the illuminating conditions of those fields, the ordinary for a half-yearly assessment test and the impact of those portions on the improvement of strain. instructional, natural, social and thriving annoys all play a fundamental farthest point inside the movement of stress. instructional parts are the most critical stressors; due to this the prerequisite for express and focused on measures to chop down out and out the largeness of weight on the experts. showing strategies and school conditions should be changed to the objectives of the investigators. The important utilization of present day understudy welfare structures, improvement of continuously undeniable 'understudy amazing' conditions and standard unpredictable extracurricular games with ordinary hypothesis can show to be profitable weight busters. further, understudies living in lodgings were organized to be inclined to widen strain; as a stop result, a coincidental examination of inns, with comments from the understudies, should be done and the court docket cases of school understudies should be quickly tended to. an enormous bit of school [1],[ 3],[5]understudies have been satisfying to strain control planning being melded inside the informational program, and hence steps ought to be taken for its hardening. wellbeing is a top of the line trouble of school understudies, and thusly the selling of solid dietary and way of life direct ought to be kept up. in addition, teachers, father and mother or conceivably school understudies themselves must be cognizant that undue suppositions concerning scholastic achievement can get strain. over the long haul, typical take a gander at quick and attractive training can help school understudies to keep up an indispensable decent ways from strain. [2 ],[ 4],[6]
\end{abstract}

Keywords : Working capital,fund,statement

\section{INTRODUCTION}

The net of all money inflows and floods all through different financial resources. Hold stream is regularly assessed on a month to month or quarterly reason. The demonstration of a

Revised Manuscript Received on July 22, 2019.

CS.Gowtham Chakravarthy, Department of MBA, Bharath Institute of Higher Education and Research, Tamilnadu, India. Email: chakravins@gmail.com

Dr.S.Praveen Kumar, Department of MBA, Bharath Institute of Higher Education and Research, Tamilnadu, Indi. Email praveenkumar.mba2bharathunuv.ac.in

G.Madhan, Department of MBA, Bharath Institute of Higher Education and Research, Tamilnadu, IndiEmail: madhangmba2gmail.com touch of room or store isn't considered, basically offer recoveries (floods) and offer buys (inflows). [13], [15] , [ 17]

Net inflows benefit for manager to contribute, which hypothetically makes energy for confirmations, for example, stocks and assurances. Cash related specialists and market investigators watch store streams to evaluate analyst feeling inside unequivocal resource classes, parts, or for the market with everything taken into account. For example, if net store streams for assurances assets during a given month is negative by a gigantic total, this would hail wide based distrust over the fixed-pay markets. [7],[ 9], [11]

\section{IMPORTANCE OF FUND FLOW ANALYSIS}

Assets stream clarification is a basic financial instrument, which separate the developments in budgetary position of a firm showing the sources and employments of its points of interest. It gives strong data about the connection's working, financing and contributing exercises during a specific period. The going with focuses feature the centrality of advantages stream announcement. [8],[ 10] ,[12]

1. Assets stream announcement helps in seeing the adjustment in level of current resources hypothesis and current liabilities financing.

2. Assets stream verbalization helps in isolating the adjustments in working capital degree of a firm.

3. Assets stream explanation shows the relationship of as a rule increment to the changes in assets from business activity.

4. Assets stream explanation reports about past store stream as a manual for imagine future finances stream. [14],[ 16], [18]

5. Assets stream verbalization helps in picking the affiliations' capacity to pay intrigue and advantage, and pay duty when they become due.

6. Assets stream explanation displays the affiliations' capacity to make entire arrangement financing to fulfill the excitement for long haul resources.

7. Assets stream explanations helps in seeing the learn in charge of changes resources, liabilities and proprietors' a motivation at two accounting report date. 
FIGURE SHOWNGGLOW OF FUND

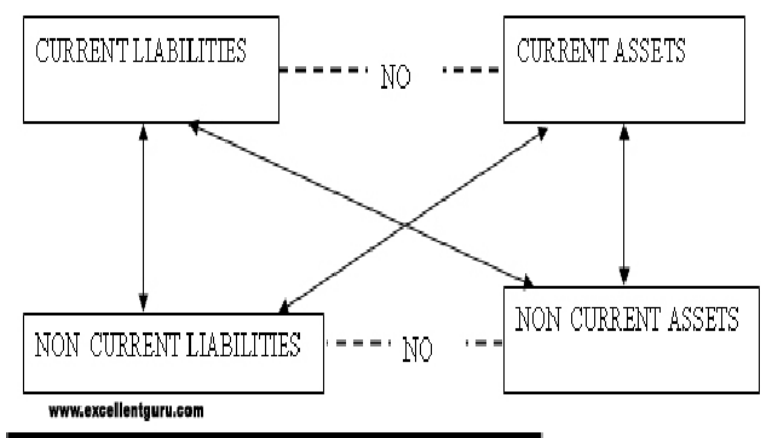

\section{Fig:1 Flow of Fund}

A. MEANING OF FLOW

1.The term 'stream' insinuates changes or move andtherefore the 'movement of benefits' strategies move of money related characteristics beginning with one asset then onto the following, fromone hazard to another, from one bit of leeway for liabilitiesor the a different way mix of these. So stream of save implies augmentation or decreasing in net workingcapital. [20],[22], [24]

2. The development or decrease in net working capital willtake place exactly when one record, out of twoaccounts to be impacted in a trade, is acurrent represent model current asset or currentliabilities and the other record is non currentaccount for instance fixed asset or whole deal commitment orcapital.

3. When a change in non current record is followedby a modification in another non current record, itdoes not mean movement of hold. It is in light of the fact that, insuch case, neither the working capital augmentation nordecrease

Disregarding the way that it's definitely not a basic work to find the definiteanswerers to such request in light of the way that fundsderived from a particular source re every so often usedfor a particular reason. In any case, certainuseful doubts can often be made and reasonable finishes are normally not difficultto connect at.

(2) Evaluation of the Firm's Financing: One huge use of the declaration is that itevaluates the firm' financing limit. The assessment of wellsprings of advantages reveals how thefirm's financed its progression stretches out in thepast i.e., from internal sources or from externalsources. It furthermore reveals the pace of improvement of the firm.

(3) An Instrument for Allocation of Resources:In present day tremendous scale business, open fundsare for each situation short for improvement programmesand there is reliably an issue of task of advantages. It is, as such, a need of evolvingan solicitation of requirements for putting through theirexpansionprogrammes which are organized in like manner, and resources must be planned as different times of ventures get into their walk. The proportion of resources for be available for these exercises will be evaluated by thefinance with the help of Funds Flow Statement. This shields the business from getting the chance to be ahelpless setback of unconstrained movement.

(4) A Tool of Communication to OutsideWorld: Funds Flow Statement helps ingathering the cash related states of Business.

It gives a comprehension into the advancement of thepresent budgetary position and offers reaction tothe issue 'where have our benefits beenmoving'? In the present universe of creditfinancing, it gives an accommodating information to associations, leasers, budgetary, it gives a usefulinformation's and government etc.regarding proportion of development required, its proposes, the terms of repayment a hotspots for repayment of development, etc the money related director gets an assurance coming about because of examination of Funds Flow Statement. Believe it or not, it passes on information concerning organization's cash related techniques to the outside world. [19],[21],[23]

(5) Future Guide: An assessment of Funds Flow Statements of a long time reveals certain huge information for the budgetary director for masterminding the future fiscal necessities of the firm and their tendency too for instance Present minute, whole deal or midterm. The organization can figure its cash related methodologies reliant on information collected from the assessment of such clarifications. Cash related boss can improve the affiliation's financing even more satisfactorily dependent on such information close by the typical changes in return p payables and the various gatherings. Thusly, it controls the organization in planning its financing more effectively[25],[27],[29]

\section{RESEARCH}

Research is a formed, effective, database, fundamental, objective, legitimate, solicitation or assessment concerning a specific issue, grasped to find answer or responds in due order regarding it. Emory describes investigate as, "any dealt with solicitation organized and did to offer information to dealing with an issue"[26],[28],[30]

\section{.IV. RESEARCH DESIGN}

\section{A. NEED FOR THE STUDY}

To appreciate that a persistent method to manage the issue is fundamental and that flitting responses may have immaterial effect.

- Data, for instance, save supports extent, commitment to-pay extent, self-evaluation of the proficiency, execution rating, and non-participation are difficult to gather as individuals may not know the cautious figures of each class or probably won't want to reveal this information[31],[33],[32]

\section{B. PRIMARY OBJECTIVES:}

To study the fund flow analysis of Infacindia 


\section{SECONDARY OBJECTIVES}

To decide the operational proficiency of the organization utilizing proportions

2. To know the progressions in fiscal summary for as long as 5 years by utilizing working capital explanation

3. To figure the future changes utilizing the pattern examination

4. To lead reserve stream explanation for 2013-2017

5. To distinguish the money related quality and shortcoming that the organization may have.

6. To dissect the connection between Net benefit and EPS utilizing Correlation investigation

\section{DATA ANALYSIS AND INTERPRETATION}

Table:1 Schedule Of Changes In Working Capital For The Year 2013 And 2014

\begin{tabular}{|l|l|l|l|l|}
\hline & $\mathbf{2 0 1 3}$ & $\mathbf{2 0 1 4}$ & INCREASE & DECREASE \\
\hline CURRENT ASSETS: & & & & \\
\hline Cash \& Balances & 51534.62 & 55546.17 & 4011.55 & \\
\hline Balance with & 15931.72 & 48857.63 & 32925.90 & \\
\hline Advances & 416768.20 & 542503.20 & 125735 & \\
\hline TOTAL CURRENT & $\mathbf{4 8 4 2 3 4 . 5 0}$ & $\mathbf{6 4 6 9 0 7}$ & & \\
\hline LESS: CURRENT & & & & \\
\hline Other Liabilities \& & 83362.30 & 110697.57 & 162672.45 & 27335.27 \\
\hline TOTAL CURRENT & $\mathbf{8 3 3 6 2 . 3 0}$ & $\mathbf{1 1 0 6 9 7 . 5 7}$ & & \\
\hline NET WORKING & $\mathbf{4 0 0 8 7 2 . 2 0}$ & $\mathbf{5 3 6 2 0 9 . 4 3}$ & & \\
\hline TOTAL & & & $\mathbf{1 6 2 6 7 2 . 4 5}$ & $\mathbf{2 7 3 3 5 . 2 7}$ \\
\hline NET CHANGE IN WC & & $\mathbf{1 3 5 3 3 7 . 1 8}$ & \\
\hline
\end{tabular}

Table:2Statement of changes in Non-Current Accounts

\begin{tabular}{|l|l|l|l|l|l|l|}
\hline Account & \multicolumn{2}{|l|}{ Balance as on } & \multicolumn{2}{l|}{ Change } & Type & Result \\
\cline { 2 - 6 } & $\mathbf{2 0 1 3}$ & $\mathbf{2 0 1 4}$ & Amount & Direction & & \\
\hline Fixed Asset & 609408.96 & 822031.57 & 212622.61 & Increase & Asset & Outflow \\
Share Capital & 631.47 & 634.88 & 3.41 & Increase & Liability & Inflow \\
Reserves & $48,401.19$ & $57,312.82$ & 8911.63 & Increase & Liability & Inflow \\
Debt & $589,131.35$ & $795,786.81$ & 206655.46 & Increase & Liability & Inflow \\
\hline
\end{tabular}

\section{Table:3 CALCULATION OF FUND FLOW STATEMENT}

\begin{tabular}{|c|c|c|c|}
\hline Sources/ Inflow of funds & RS & $\begin{array}{l}\text { Application/ Outflow of } \\
\text { funds }\end{array}$ & Rs \\
\hline Share Capital & 3.41 & Fixed Asset & 212622.61 \\
\hline Reserves & 8911.63 & Fund Flow operation & 135337.18 \\
\hline Debt & 206655.46 & & \\
\hline \multirow[t]{2}{*}{ Net Increase in WC } & 132389.29 & & \\
\hline & 347959.79 & & 347959.79 \\
\hline
\end{tabular}

\section{INFERENCE:}

- The Net decrease in Working capital for the year $2013-2014$ is 132389.29

- The fund flow operation for the year 2013-2014 is 135337.18

Table :4 Schedule Of Changes In Working Capital For The Year 2014 And 2015

Statement of changes in Non-Current Accounts

\begin{tabular}{|l|l|l|l|l|l|l|}
\hline Account & \multicolumn{2}{|l|}{ Balance as on } & \multicolumn{2}{l|}{ Change } & Type & Result \\
\cline { 2 - 5 } & $\mathbf{2 0 1 4}$ & $\mathbf{2 0 1 5}$ & Amount & Direction & & \\
\hline Fixed Asset & 822031.57 & 921822.05 & 99790.48 & Increase & Asset & Out flow \\
Share Capital & 634.88 & 634.88 & - & Nochange & Liability & No flow \\
Reserves & $57,312.82$ & 65314.32 & 8001.50 & Increase & Liability & Inflow \\
Debt & $795,786.81$ & 907127.83 & 171341.02 & Increase & Liability & Inflow \\
& & & & & & \\
\hline
\end{tabular}

Table:5 CALCULATION OF FUND FLOW STATEMENT 


\begin{tabular}{|l|l|l|l|}
\hline Sources/ Innow of funds & RS & $\begin{array}{l}\text { Application/ Outnow of } \\
\text { funds }\end{array}$ & Rs \\
\hline Reserves & 8001.50 & Fund flow operation & 111551.92 \\
$\begin{array}{l}\text { Debt } \\
\text { Increase in WC }\end{array}$ & 171341.02 & Fixed assets & 99790.48 \\
\hline & 31999.88 & & \\
\hline & 211342.40 & & 211342.40 \\
\hline
\end{tabular}

INFERENCE:

The Net Increase in Working capital for the year 2014-2015 is 31999.88

The fund flow operation for the year 2014-2015 is 111551.92

\section{RESULTS}

The Net abatement in Working capital for the year 2013 2014 is 135337.18

2. The reserve stream activity for the year 2013-2014 is 142545.18

3. The Net abatement in Working capital for the year 2014-2015 is 9288332.39

4. The reserve stream activity for the year 2014-2015 is 9579226.83

5. The Net Increase in Working capital for the year 2015-2016 is 126583.58

6 . The reserve from activity for the year 2015-2016 is 9594259.74

7. The Net Increase in Working capital for the year 2016-2017 is 109481.34

8. The store from activity for the year 2016-2017 is 53277.56

9. The current year (2017) current proportion is observed to be the most elevated (11.92) because of the lessening in the liabilities.

10. The current year (2017) money position proportion has expanded to 1.20 when contrasted with the earlier year 2016 with 1.17 .

11. The current year (2017) restrictive proportion is observed to be 0.06286 it is in an expanding position.

\section{The Standard Deviation for NP is $\mathbf{1 7 3 5 . 1 2}$}

13. The standard deviation of Cash and friends parity is 17862.287

14. There is a high level of relationship between's Net benefit and EPS on the grounds that the connection esteem (0.995787) is more than 0.05. It gauges the closeness of connection between Net benefit and EPS and the two of them have a positive relationship.
15. The current year(2017) return on investors value is expanded to 17.45

16. In the year 2016 the Debt-value proportion is higher which implies that the organization is having a higher influence.

17. In the year 2017 the Fixed resource proportion is expanded to 0.0044 . This implies the organization's fixed resource position is palatable

18. On the year 2017 the Return on Asset is higher. Accordingly higher estimations of profit for resources demonstrate that business is progressively productive

19. The present year obligation to add up to resource proportion is expanded to $87.65 \%$ when contrasted with the earlier year $86.09 \%$.

\section{DISCUSSION}

There are distinctive overall challenges that are looked by every association in the present centered condition and Infac India isn't any rejection. To go up against the present overall troubles the HR division should be make to improve various capacities among the laborers remarkably the powerful aptitudes and having the standard getting ready for the agents about various headways in the market.

1. The current assets should be directed even more effectively so as to avoid pointless deterring of capital that could be used for various purposes.

2. The Working Capital essential is to be assessed subject to the guidelines coursed by RBI

3. The association has kept up genuine records exhibiting full focal points, quantitative nuances and game plans of fixed assets are appeared for noteworthy things in the register, the organizations during the year has coordinated a self-assertive affirmation in respect of fixed assets, which as we might want to believe is reasonable, having admiration to the size of the association and the possibility of its focal points.

\section{CONCLUSION}

The association is performing particularly well due to the up wising in the overall market sought after by the private market. It is an approaching one with extraordinary and innovative considerations and put confidence in improving all of the regions of its assignments. The association has a better than average liquidity position and does not concede its commitment in genuine cash of the two its banks and obliged people. The association being commonly dependent on the working capital workplaces, it is keeping up incredible relationship with their associations and their working capital organization is especially balanced.

\section{REFERENCES}

1. G BharthVajan R., Ramachandran S.,Psychographic dimensions of training,2016,International Journal of

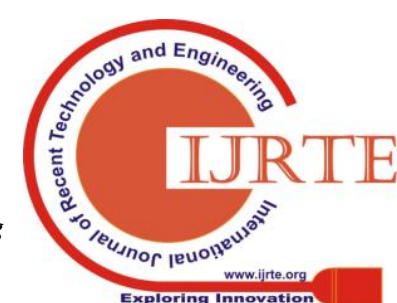


Pharmacy and Technology,V-8,I-4,P-23727-23729

2. Balakrishnan P., Bharthvajan R.,A study on human resource planning in hospitals in Chennai City,2014,International Journal of Applied Engineering Research,V-9,I-22,P-7503-7507

3. Priyadarsini P., Bharthvajan R.,Role of emotional intelligence training programme in reducing the stress of the nurses,2014,International Journal of Applied Engineering Research,V-9,I-22,P-7411-7421

4. Kerinab Beenu G., Bharthvajan R.,Empirical analysis on the cosmetic buying behavior of young women in South India,2014,International Journal of Applied Engineering Research,V-9,I-22,P-7361-7366

5. Balakrishnan P., Bharthvajan R.,Whistling in the wind,2014,International Journal of Applied Engineering Research,V-9,I-22,P-7586-7593

6. Krishnan B., Peter M.,Health hazards of Indian Bpo employee-an alarming issue,2014,International Journal of Applied Engineering Research,V-9,I-22,P-7336-7341

7. Kerinab Beenu G.H., Peter M.,Role of insurance in economic development,2014,International Journal of Applied Engineering Research,V-9,I-22,P-7532-7539

8. Balakrishnan P., Peter M., Priyadarsini P.,Efficiency of safety measures for wellbeing of employees in manufacturing industry,2014,International Journal of Applied Engineering Research,V-9,I-22,P-7376-7382

9. Anbarasi M., Praveen Kumar S.,Online sales promotions of herbal products and its effectiveness towards tanisha.com,2019,Indian Journal of Public Health Research and Development,V-10,I-1,P-195-200

10. Anbarasi M., Praveen Kumar S.,Various online marketing and promotions strategies to improve the validation towards the organic products in the pharmaceutical sectors,2019,Indian Journal of Public Health Research and Development,V-10,I-1,P-263-269

11. Loganathan R., Praveen Kumar S.,Grievance handling a key factor for solving issues of employees in an organization,2014,International Journal of Applied Engineering Research,V-9,I-22,P-7483-7491

12. Loganathan R., Praveen Kumar S.,Study on preference of private label brands in super and Hypermarkets,2014,International Journal of Applied Engineering Research,V-9,I-22,P-7327-7335

13. Smitha M., Praveen Kumar S.,Understanding stress and its managementamong the nurses in Chennai city,2014,International Journal of Applied Engineering Research,V-9,I-22,P-7560-7565

14. Kerinab Beenu G.H., Praveen Kumar S.,A study on the investment behavior of Chennai investors in mutual fund schemes,2014,International Journal of Applied Engineering Research,V-9,I-22,P-7520-7525

15. Loganathan R., Praveen Kumar S.,Retention strategies key for organizational productivity,2014,International Journal of Applied Engineering Research,V-9,I-22,P-7443-7447

16. Pavithra J., Ganesan M., Brindha G.,State wise analysis of microfinance sector in India,2016,International Journal of Pharmacy and Technology,V-8,I-4,P-23417-23432

17. Pavithra J., Ganesan M.,A comparative study on microfinance in India and abroad,2016,International Journal of Applied Business and Economic Research,V-14,I-8,P-5471-5476

18. Pavithra J., Ganesan M.,A study on awareness and impact of micro-financial schemes,2016,International Journal of Applied Business and Economic Research,V-14,I-8,P-5449-5460

19. Senthilmurugan P., Pavithra J.,Consumer preference towards organised retailing with reference to Big Bazaar,2014,International Journal of Applied Engineering Research,V-9,I-22,P-7469-7475

20. Senthilmurugan P., Pavithra J.,Implication of social media marketing in growing healthcare industry,2014,International Journal of Applied Engineering Research,V-9,I-22,P-7448-7456

21. Loganathan R., Pavithra J.,Consumer perception towards private label brand over other brands in super markets and hypermarkets,2014,International Journal of Applied Engineering Research,V-9,I-22,P-7355-7360

22. Kerinab Beenu G., Pavithra J.,Tradeâ€"off between liquidity and profitability in logistics industry,2014,International Journal of Applied Engineering Research,V-9,I-22,P-7398-7401

23. Kerinab Beenu G., Pavithra J.,A study on the prospective consumerâ€ $€^{\mathbf{T M}_{S}}$ perception towards utility cars in Chennai city,2014,International Journal of Applied Engineering Research,V-9,I-22,P-7526-7531

24. Pavithra J., Dilli Babu P., Ambuli T.V.,A study on budgetary control at Maruti Service Masters, Chennai,2014,International Journal of Applied Business and Economic Research,V-12,I-2,P-151-161

25. Pavithra J., Dilli Babu P., Ambuli T.V.,A study on customer satisfaction of retro Garments Pvt Ltd, Chennai,2014,International Journal of Applied Business and Economic Research,V-12,I-2,P-381-391

26. Kerinab Beenu G.H., Pavithra J., Senthilmurugan P.,A study on the influence of promotional activities for TATA ARIA among consumers in Chennai,2014,International Journal of Applied Engineering Research,V-9,I-22,P-7572-7578
27. Vijayaragavan S.P.,An investigative expert that's general FBG sensors,International Journal of Mechanical Engineering and Technology,V-8,I-8,PP-1500-1505,Y-2017

28. Vijayaragavan S.P.,Equalization routing protocol for Wi-Fi sensor strategy,International Journal of Mechanical Engineering and Technology,V-8,I-8,PP-1662-1666,Y-2017

29. Karthik B., Kiran Kumar T.V.U., Vijayaragavan P., Bharath Kumaran

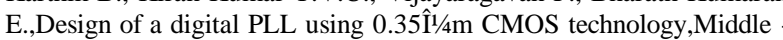
East Journal of Scientific Research,V-18,I-12,PP-1803-1806,Y-2013

30. Kanniga E., Selvaramarathnam K., Sundararajan M.,Kandigital bike operating system,Middle - East Journal of Scientific Research,V

31. Jasmin M., Vigneshwaran T., Beulah Hemalatha S.,Design of power aware on chip embedded memory based FSM encoding in FPGA,International Journal of Applied Engineering Research,V-10,I-2,PP-4487-4496,Y-2015

32. Jasmin M.,Optimization techniques for low power VLSI circuits,Middle East Journal of Scientific Research,V-20,I-9,PP-1082-1087,Y-2014

33. Jasmin M., Vigneswaran T.,Fuzzy controller for error control of on - Chip communication,2017 International Conference on Algorithms, Methodology, Models and Applications in Emerging Technologies, ICAMMAET 2017,V-2017-January,I-,PP-1-5,Y-2017

\section{AUTHORS PROFILE}

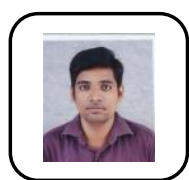

CS.Gowtham Chakravarthy, Assistant Professo ,Department of MBA, Bharath Institute of Higher Education and Research, Tamilnadu, India

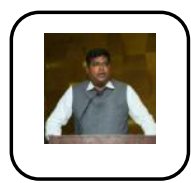

Dr.S.Praveen Kumar,Professor ,Department of MBA, Bharath Institute of Higher Education and Research, Tamilnadu, India

G.Madhan, Student ,Department of MBA, Bharath Institute of Higher Education and Research, Tamilnadu, India 